\title{
Relations between sociocultural spaces and the consumption of psychoactive substances by adolescents
}

\author{
Relação entre espaço sociocultural e o consumo de substâncias psicoativas por adolescentes
}

Relación entre el espacio sociocultural y el consumo de

sustancias psicoactivas por adolescentes

\section{Camila Souza de Almeida ${ }^{a, b}$ \\ Francisco Carlos Félix Lana ${ }^{a}$}

\section{How to cite this article:}

Almeida CS, Lana FCF. Relations

between sociocultural spaces and the consumption of psychoactive substances by adolescents. Rev Gaúcha Enferm. 2020;41:e20190335. doi: https://doi. org/10.1590/1983-1447.2020.20190335 aniversidade Federal de Minas Gerais UFMG), Escola de Enfermagem, Programa de Pós-graduação em Enfermagem. Belo Horizonte, Minas Gerais, Brasil.

${ }^{b}$ Universidade do Estado de Minas Gerais (UEMG) Divinópolis, Minas Gerais, Brasil.

\section{ABSTRACT}

Objective: To understand the relation between space and psychoactive substance use by adolescents.

Methods: This is a mixed method study conducted with 9th grade students from an elementary school in Divinópolis, Minas Gerais. In the quantitative phase ( $n=303$ ), the modules for general information, use of beverages and illegal drugs from the National School Health Survey were applied. The qualitative phase $(n=18)$ was dominant and followed the quantitative. Descriptive and associated factor analyses were performed for the quantitative variables. Concerning the qualitative aspects, speeches were analyzed based on social determination.

Results: Not living with parents and having friends that drink were factors associated with a higher probability of drinking by adolescents. The adolescents' sociocultural spaces are related to the use of beverages and their consequences.

Conclusion: The adolescents'views regarding the use of psychoactive substances are influenced by the social and geographical space in which they are inserted.

Keywords: Adolescent behavior. Substance-related disorders. Family relations. Schools. Interpersonal relations

\section{RESUMO}

Objetivo: Compreender a relação entre espaço e uso de substâncias psicoativas por adolescentes.

Métodos: Pesquisa de método misto, conduzida com escolares do $9^{\circ}$ ano do ensino fundamental de Divinópolis, Minas Gerais. № eixo quantitativo (n=303) aplicou-se os módulos de informações gerais, uso de bebidas e drogas ilícitas da Pesquisa Nacional de Saúde do Escolar. 0 eixo qualitativo ( $n=18)$ foi preponderante e seguiu-se ao quantitativo. Realizou-se análise descritiva e de fatores associados para as variáveis quantitativas. No qualitativo analisou-se os discursos com base na determinação social.

Resultados: Não morar com os pais e ter amigos que fazem uso de bebidas foram fatores associados a uma maior probabilidade de uso de bebidas por adolescentes. Os espaços socioculturais do adolescente relacionam-se com o uso de bebidas e suas consequências. Conclusão: A visão do adolescente quanto ao uso de substâncias psicoativas é influenciada pelo espaço social e geográfico no qual se insere.

Palavras-chaves: Comportamento do adolescente. Transtornos relacionados ao uso de substâncias. Relações familiares. Instituições acadêmicas. Relações interpessoais.

\section{RESUMEN}

Objetivo: Comprender la relación entre el espacio y el uso de sustancias psicoactivas por parte de los adolescentes.

Métodos: Una investigación de métodos mixtos, realizada con estudiantes de novena grado de la escuela primaria en Divinópolis, Minas Gerais. En el eje cuantitativo ( $n=303$ ) aplicamos los módulos de información general, uso de drogas y drogas ilícitas de la Encuesta Nacional de Salud Escolar. El eje cualitativo $(n=18)$ fue predominante y siguió al cuantitativo. El análisis descriptivo y los factores asociados se realizaron para las variables cuantitativas. En lo cualitativo analizam os los discursos basados en la determinación social.

Resultados: No vivir con padres y tener amigos que usan bebidas fueron factores asociados con una mayor probabilidad de consumo de alcohol por parte de los adolescentes. Los espacios socioculturales de los adolescentes están relacionados con el uso de bebidas y sus consecuencias.

Conclusión: La visión del adolescente sobre el uso de sustancias psicoactivas está influenciada por el espacio social y geográfico en el que se inserta.

Palabras clave: Comportamiento del adolescente. Trastornos relacionados con sustancias. Relaciones familiares. Instituciones académicas. Relaciones interpersonales. 


\section{口INTRODUCTION}

The consumption of psychoactive substances (PAS) occurs in all cultures, with alcohol being one of the most used substances, causing serious short- and long-term health damage ${ }^{(1)}$. Its use by adolescents is considered high in developing countries, such as Brazil and China. In in the latter, consumption among adolescents between 12 and 17 years old, in the 30 days prior to the survey, was $42.2 \%$, while in Brazil, a study conducted in Belo Horizonte, Minas Gerais, reported an increase in binge drinking (episodic heavy drinking) in the period from 2010 to 2012, going from 35.6\% to 39.9\%(2).

The 2015 National School Health Survey (PeNSE, 2015)(3), carried out with 9th grade elementary school adolescents, reported that 23.8\% used alcoholic beverages over a period of thirty days, with a prevalence of $22.5 \%$ in boys and $25.1 \%$ in girls, and an overall prevalence use of $55.5 \%$. This early use of alcohol in adolescence can alter brain development, influencing behavioral, emotional and social development ${ }^{(4)}$.

These high results in adolescence are related to the contemporaneity in which there is a homogenization of needs. The use of PASis one of these needs, making it so the consumption is considered necessary depending on the space occupied socially by an adolescent ${ }^{(5)}$.

The geographic and social space that the teenager occupies and interacts is a strong social object, since it is part of everyday life, largely conditioning his social practices. Space can be considered a product of human action, being linked to its historical past and the struggles and interests of the groups that occupy or wish to occupy it ${ }^{(6)}$.

Geographic spaces are homes to institutions such as schools, churches, bars and houses, which are organized by individuals and social groups according to their experiences and historical background. Thus, each social group organizes and produces its own space as a place for its own reproduction and historical reaffirmation ${ }^{(6)}$.

When discussing the use of PAS by adolescents, the spaces occupied by them deserve to be highlighted, as it is at this stage of life that individuals search for connections and interactions and there is a need to belong to a group ${ }^{(7)}$. Among these spaces are the family and the school. The family would be an important source of social relationships, being the first institution in which the individual socially interacts. In adolescence, the school emerges as an essential space for social interaction, thus opening a range of interactions and actions that shape young people while modifying their space ${ }^{(6)}$.
The consumption of PAS occurs in all these spaces, meaning the phenomenon is cosmopolitan and multifactorial, involving both singular and global determinations. The global determination of the phenomenon is understood as the macrosocial dimension, considering the health-disease process at the collective level.The singular dimension unfolds in social groups and the singular processes that occur in the daily lives of individuals is influenced by their genotype ${ }^{(8)}$.

Thus, when discussing the phenomenon of the PAS use by adolescents, purely descriptive data cannot cover the complexity of the problem. The statistical description should give support to a complex discussion, always considering the factors being used, but at the same time, discussing its interface with the spaces in which the phenomenon unfolds ${ }^{(6)}$.

Based on the above, it is necessary to understand the relationship between space and use of PAS by adolescents in a broad way, as long as the professionals who attend these adolescents in the health, education, or judicial systemsdo not blame only the individual for the use, but understand that the phenomenon involves space, meaning that health units, schools and rehabilitation places are the protagonists, not the individuals.

This article was extracted from a thesis that had four chapters that discussed the social determinants of the use of PAS in the view of adolescents. The chapter that served as the basis for this article analyzed the adolescents' social space and the use of PAS.

\section{METHOD}

The study used a mixed research method, a type of research that collects and analyzes both qualitative and quantitative data. The strategy adopted was the sequential exploratory (Quan QUAL). The qualitative data was prioritized, and the results of both designs were integrated in the interpretation of the data based on the theoretical reference $e^{(9)}$.

The quantitative phase first led to the establishment of a bond with the adolescents, as the theme addressed is sensitive and surrounded by taboos. Thus, many students might not feel comfortable exposing their experiences in the qualitative part, in addition to the fear of having their answers available to the school and/or guardians. Through the application of the quantitative phase first, mutual trust was created, which facilitated the semi-structured interviews. In addition, the analysis of quantitative data was expected to recognize gaps and possible important issues for the qualitative phase. 
The study was conducted with adolescents who were in the 9th grade of an elementary school (average age of 14 years old) in the city of Divinópolis, Minas Gerais. The choice of this sample is justified because they have the minimum level of education to answer a self-administered questionnaire, in addition to being the same age group used by the 2015 National Student Health Survey, whose questionnaires related to general information and alcohol ingestion were used in the quantitative design of this research ${ }^{(3)}$. The research happened from May 2017 to March 2018.

The quantitative stage was a cross-sectional study, in which the modules for general information and the use of alcoholic beverages from the National School Health Survey (PeNSE) in $2015^{(3)}$ were applied.

Regarding the questions about experimentation and alcohol use, the PeNSE(2015) $)^{(3)}$ contains eight questions, which refer to the adolescent having already tried drinks, and if so, what was their age, how many days of use in the month, number of doses taken in the last 30 days, form of drinking, problems related to use, such as missing school or family discussions, and having friends who drink.

The study followed the same sampling criteria as the original survey ${ }^{(3)}$. The sample size was calculated to provide estimates of the prevalence of alcohol consumption in the last 30 days by 9 th grade adolescents, estimated at around $23 \%$ for Brazil ${ }^{(3)}$. Considering a population of 3.000 th grade students, with a maximum sampling error of $5 \%$, in absolute values, a confidence level of $95 \%$ and a sampling plan effect (effect of the sample design of clusters) of 1.5; a sample of approximately 375 9th grade students was estimated, already considering possible losses.

Considering the average number of 30 students per class, a sample of approximately 13 schools $(=375 / 30)$ was estimated, distributed proportionally between public and private schools. Approximately $15 \%$ of the 9 th classes in the city were in private schools and $85 \%$ in public schools. Thus, following the proportional distribution, the sample was composed of two private and 11 public schools. The schools were selected by simple random drawing. Considering the expected refusals and losses, 303 respondents were obtained from the 13 selected schools.

The researcher applied the modules in the institutions themselves, without the presence of teachers. Before the application of the quantitative questionnaire, all classes were visited and informed about the research.

The inclusion criteria used were: being regularly enrolled in the 9th grade of elementary schools in the selected schools and being present in the classroom on the day scheduled to talk about the project, as well as on the day the questionnaire was applied. The exclusion criteria were: not being present at the time of the first contact, as well as on the day the questionnaire was applied. For adolescents who had any limitations for self-completing the questionnaire, the supervisors of these students were asked to assist them in a place reserved for this purpose, without interference from teachers.

During data analysis, initially, a general description of the variables was made, with frequency distribution, measures of central tendency (mean), variability (standard deviation) and position (median, minimum and maximum). In a second step, the factors of alcohol use by adolescents were associated, based on the theoretical reference of social determination ${ }^{(8)}$. The response variable used was "Have you ever drunk alcohol?", categorized as yes or no. The explanatory variables were grouped into categories of covariates. As this article is an excerpt, the co-variables analyzed and discussed here were: gender (male/female); type of school (public or private); with whom the adolescent lives (father and mother/only mother / neither father nor mother); maternal educational level (studied until elementary/high school or higher) and friends who drink (yes/no).

The collected data were stored and organized in an electronic spreadsheet and analyzed with the aid of the statistical program STATA, version 12.0. A descriptive analysis of all the studied variables was performed and the prevalence of alcohol consumption in life was estimated with a 95\% confidence interval $(95 \% \mathrm{Cl})$.

To assess possible factors associated with alcohol consumption in the univariate analysis, Pearson's chi-square test was used. Then, the Poisson model with both simple and multiple robust variances was used. For the variables' entry in the multiple analysis a reference a p-value less than 0.20 in the univariate analysis was used. In the final model, only variables with a significance level equal to or less than 5\% remained. Prevalence Ratio (PR) values were estimated, with a $95 \%$ confidence interval $(95 \% \mathrm{Cl})$.

After the analysis of the quantitative data, a qualitative phase followed. Based on the theoretical reference and the analysis of the quantitative data, the semi-structured script was applied. The six schools with the largest number of students from the 9th grade among the elementary schools who had participated in the first stage were selected.

The schools selected were: a municipal public school, located in a peripheral neighborhood, four state public schools with different contexts, and a private school located downtown. After the schools were chosen, three students 
per institutionwere drawn, to increase the diversity of views about the phenomenon. If the 18 students interviewed had not reached theoretical and data saturation, new interviews would have been carried out. However,data saturation was achieved with the first 18 interviews ${ }^{(10)}$. The criteria for the selection of participants in the qualitative phase was to have participated in the previous phase and to be at school on the day scheduled for the semi-structured interview. The exclusion criteria were: not being present on the day of the interview or being in another school activity.

Data collection was at the schools, in a private place, during class hours. The interview time lasted for an average of 25 minutes and a recorder was used, with authorization from the participants.

Alphanumeric codes were used to identify the interviewees, made up from the letters $\mathrm{M}$ (male) or $\mathrm{F}$ (female), followed by the number of the interview. All interviews were recorded and immediately transcribed in full by the researchers, using double typing. The field diary was an important tool for the interpretation of the research data and its discussion.

The qualitative results were interpreted using Hermeneutics-dialectic, because the studies should include the meaning the adolescents attribute to the use of PAS, not to mention that this strategy is in accordance to the theoretical reference ${ }^{(11)}$. The research took place in the following order: data organization, classification and final analysis. All steps were dynamic and complementary ${ }^{(11)}$.

The organization occurred with the reading of the interviews together with the field diary. The classification made it possible to construct the sense nuclei, in which horizontal and vertical syntheses were carried out. The horizontal synthesis allowed the observation of differences and similarities in the interviewees'statements, while in the vertical synthesis it was possible to generalize and have a global idea about the perception of each interviewee.

Then, a cross-sectional reading of all the material was carried out, comparing it with the theoretical reference and the field diary. Based on this reading, the fundamental determinations were made, which consisted of a summary of the field observations of each school together with the cross-sectional and horizontal analyses of the meanings. With these steps, the fundamental general determination of all interviews was built. After these steps, three categories emerged from the qualitative analysis.

In the final analysis, the sequential transformational strategy was used, and the quantitative and qualitative phases were integrated and interpreted in the light of the theoretical reference, leading to the creation of four chapters on the theme ${ }^{(9)}$. This article will discuss the Thesis chapter entitled "The adolescents' relations and social spaces and their associations with the use of PAS".

This project was approved by the UFMG Research Ethics Committee, under protocol No. 2.007.097. The selected individuals signed the free and informed consent form (FICF) and since this is a study involving adolescents, the guardians consented to their participation through the Informed Consent Form (ICF). The research complies with Resolution 466/12 of the National Health Council.

\section{RESULTS}

The quantitative phase had a representative sample of 303 adolescents who were in the 9th grade of elementary schools during 2017, of which $54.7 \%$ ( $n=158$ ) were male, with an average age of 14 years. As for the alcohol use module, 298 adolescents answered whether they had used drinks in their lifetime. 50.3\% ( $n=150)$ had, a group whose average age was 13 years of age (12.8 \pm 1.9). Table 1 shows univariate analyses for the determinants associated with alcohol consumption, relevant to the discussion of the article.

According to the results of the multiple model (Table 2), living with neither father nor mother, in addition to having friends who drink, were factors associated with a higher probability of using alcoholic beverages.

The use of illicit drugs was reported by $7.7 \%(n=23)$ of the students, of those who had used drugs until that point in life, the use of marijuana in the last month was reported by $54.2 \%(n=12)$, and $4.3 \%(n=1)$ consumed crack.

In the second phase (QUAL), 18 participants were interviewed, in which $50.0 \%(n=9)$ were girls, with an average age of 14 years. In the first subcategory on the theme of social space and the interpersonal relationships of the adolescent, the link between the school and the theme of PAS was analyzed. The students reported that the subject is rarely addressed in the institutions, regardless of the type of school or location. This information is in accordance with the quantitative data,since there were no different rates of PASuse between public and private schools, demonstrating that both the use and the way of approaching the issue are similar between the institutions of the city.

When the topic is discussed, it occurs during biology or religious education classes, demonstrating a biomedical view or a morality-related one, a paradigm that is dominant today. 
Table 1 - Univariate analysis of the assessment of factors associated with alcohol consumption. Divinópolis, MG, Brazil, 2017

\section{Total Frequency Alcohol prevalence use $\quad$ p-value* $\quad \mathbf{P R}^{\dagger}[\mathrm{Cl} 95 \%]^{\ddagger}$}

\section{Type of school}

Private

Public

\section{Gender}

Female

Male

Mother's educational level

Elementary or lower

$74(34.7 \%)$

$39(53.4 \%)$

0.485

$29(43.3 \%)$

High School

68 (31.9\%)

$71(33.3 \%)$

$34(47.9 \%)$

0.166

$1.17[0.93 ; 1.48]$

College

\section{Who do you live with}

Mother and Father

$190(64.0 \%)$

Just Mother

$95(32.0 \%)$

$86(45.7 \%)$

0.023

$51(54.8 \%)$

$12(4.0 \%)$

$10(83.3 \%)$

$<0.001$

$0.81[0.57 ; 1.15]$

$0.90[0.65 ; 1.24]$

Neither mother nor father

\section{Friends that drink}

\begin{tabular}{|c|c|c|c|}
\hline No & $24(8.8 \%)$ & $3(13.0 \%)$ & 1 \\
\hline Yes & $249(91.2 \%)$ & 139 (56.0\%) & $4.30[1.48 ; 12.44]$ \\
\hline
\end{tabular}

Source: Research data, 2017.

Legend: * p-Percentile; PR - ${ }^{\dagger}$ Prevalence ratio; ${ }^{\ddagger} 95 \%$ Cl - 95\% Confidence Interval.

Table 2 - Multivariate analysis of the factors associated with alcohol consumption by students in the 9th grade of elementary school. Divinópolis, MG, Brazil, 2017
Variable
p-value*
$\mathbf{P R}^{+}[\mathrm{Cl} 95 \%]^{\ddagger}$

\section{Who do you live with}

Mother and Father

Just Mother

0.281

$3.87[0.89 ; 1.47]$

Neither mother or father

0.010

$1.44[1.09 ; 1.90]$

\section{Friends that drink}

No

0.009

Yes

$3.87[1.40 ; 10.66]$ 
[...] just a small mention when they are going to talk about organs ... lung ... heart ... these things, but most of the time there is nothing. Only a few lectures about cigarettes, drinks and drug use, but this is very rare (M6).

She [religion teacher] talks about the harm and all, why the person is led to this, what happens (F14).

The statement of the adolescent that will be presented below (F11) is interesting because she reports that the institution should not address the subject, as it would not be their responsibility. The adolescent is a student at the most socially vulnerable school, a place whose manager, in a conversation with the researcher,stated that many students at that school "wouldn't go anywhere".

No, they never talk about drugs, ever, because it's not their business (F11).

Some students said that,at their school, the police were called in due to a student being approached with illicit drugs, as shown below:

They don't really care [they should talk about it]. These days, a boy brought it, right? And he was at the back smoking and he got high. Call the police, right? The boy feeling sick, besides calling .... Call the police (F11).

The consumption of PASdoes not occur only in the more distant neighborhoods, a state school located in an upscale neighborhood of the city was also the scene of an episode in which a student arrived drunk. This abuse was pointed out by the quantitative data as there were no differences in use between types of school.

I think there was a student who was drunk, then the teachers talked to him and everything, but not in class... not even in religion classes! I thought it was weird (M1).

What differentiates one episode from the other is the school's approach to the use of PAS, demonstrating the social difference of the phenomenon.

Still regarding the school's approach to the topic, the private sector discusses the use of PAS throughout the semester, through social projects that take adolescents to rehabilitation clinics and lectures given at school.
I think last year there was a lecture, I was there, that talked about the use of alcohol and drugs too. Some people came to talk to us, they were ex-users, explaining why. There's "citizen of the world", the project that talks about drug use (M18).

In public schools, the theme is addressed in the Drug Resistance Educational Program (Proerd), in the 6th year of elementary school and demonstrates a vision of the use of PAS related to prohibition and biologicism.

Sometimes the subject is discussed. There are teachers that talk about it. They talk about the effects, what it causes .... When we had it, it was Proerd, right?! And in some classes, from time to time some questions about it is on tests, but only a few (F2).

When asked if they thought the school should address the subject, they answered yes, since the use of PAS is a reality to be discussed.

Sure [it would be important to address the topic]. Because, you see, we are here at school and if they are raising our awareness ... We will be aware of what will happen outside, you will know to say no (F10).

But although the subject is considered relevant, it is still a taboo, and schools that promote discussions of the topic may face resistance from parents and students. As presented in the speech of $\mathrm{M} 18$, who studies at a private school.

Well, I think that in relation to the lectures I am in favor, which is a way for people to see and understand the other side of the story and learn not to judge. But regarding projects in which you must go to institutions, I think it depends a lot on age. I'm not that ok whit that. I'll give you an example: the $C * * *$ [therapeutic community], l even wanted to go last year, but then I sat down and talked to my parents and they even explained it, and I thought better, because I think it depends of the person, I can't say that I can go because I am strongly emotional or something. Because I don't know how it is there, I know that their situation is sad and I think it is too early for a person, who is still young, to know this world (M18). 
The second subcategory shows family relations and the consumption of PAS, considering that all adolescents have at least one relative in their environment who abuses or abused PAS. The SPAs are consumed at parties and in the teenagers' own houses, mainly on holidays or as a way of welcoming friends. Although it is considered sociable, the adolescents report discussions and episodes of violence due to the excessive use of alcohol during these occasions.

It's like on weekends, almost every weekend and at parties, like the end of the year ... Easter, at these times they [family members] usually drink a lot! And because of the drinking, they end up doing things they didn't normally do... then it makes a lot of confusion. That's why I don't go much to these family parties, because I don't like to see these things (M6).

The offer of alcohol as a way to welcome friends and family can be considered a social standard, since those responsible for adolescents have friends and family members who use it and adolescents end up reproducing this behavior when associating with individuals who use alcohol, in addition to using it as a way of socializing. A fact that appears on the quantitative results, is that the adolescents who have friends who drink are more likely to drink too. The following statements from F13 and F14 corroborate what was reported above.

Well, when they (parents) are home and are not going out, then they drink, even if it's just a glass, but they drink (F13).

My parents hardly use it. My mom practically doesn't drink, she doesn't like it and my dad just sometimes. Just sometimes... He doesn't like drinking much. When someone comes to the house, he drinks a little with them or on some weekends and such [...] (F14).

Regarding the specific use by parents or guardians, the statements indicate that the majority drinks at home, especially on weekends. The use by mothers is less frequent, being mentioned as "social use", but the term is difficult to measure, as it will depend on the reality of each family.

Only my father [drinks], my mother drinks only socially. She drinks only Martinis or wine. My father drinks every day ... Not every day, but Friday, Saturday and Sunday.
Like, Saturday he starts after lunch and drinks until five, Sunday too (M15).

The use of beverages, despite being an important socializing factor for families, showed a relationship with accidents caused by their abusive use, which occurred mainly with the parents of adolescents.

But my father drinks, but he stays normal, he doesn't lose control. There was a time when he drank so much that he even crashed the car [demonstrates the crash with gestures and laughter] Yeah.... That's it. Then I told him to stop drinking (M4).

[father] A few "pingas" [typical and strong Brazilian spirit], a liter a day. He already had an accident because of that ... he was riding a bicycle like that [noise] then a motorcycle came and got him. He was dizzy (F5).

Adolescents have their primary socialization institution in the family and it is by observations their behaviors that they learn about standards considered acceptable or not. When integrating the adolescents'statements and statistical data, family behavior in relation to the use of drinks and the social vulnerability to which they may be exposed are related to the consequences of use, as can be observed, since adolescents who do not live with parents are more likely to use alcohol and a higher maternal education is not associated with consumption, being a protective factor for adolescents.

Regarding the use of illicit drugs, three adolescents talked about the use by their parents, with more serious short-term consequences than drinking. One parent died, another was incarcerated, and the third was in a rehabilitation clinic. The first two are parents of students that live in a region of great social vulnerability, and the latter lives in one of the most upscale regions of the city.

My dad used drugs and stuff. [The father's death] it was an accident, right? He was, right? [Under the influence of PAS]. It was an accident ... an accident at home, left the gas on, went to light the lighter and [...] (F11).

I have a father who has a problem with this [drugs], he is in a rehabilitation clinic [...] He (father) stopped a little [PAS use] after he left the clinic. In fact, he didn't want to leave the clinic because he thought it was being good for him, so after he left hecouldn't control himself (M1). 
Now he is in prison [father], but earlier, when I visited him, he drank a lot, but I never got to see him "tripping", about to fall. But I knew he drank because he drank at home and he drank a lot and I don't know, but I think he used other things (F10).

The reports show that the use of illicit drugs is widespread among social classes. What changes are the consequences of this use, according to the social status occupied by the individual. While $\mathrm{M} 1$ father is in a private rehabilitation clinic, the other two individuals found themselves in different destinations: one died and the other is in prison due to association with drug trafficking. Both skin color - both $\mathrm{F} 10$ and F11 are black and M1 is white - and the space occupied by them dictates their social position.

The consumption of PAS, as shown, causes family conflicts, resulting in psychological and physical aggressions.

Because he [father] was taken over by jealousy, he sometimes attacked her [mother]. I was sad, I was trying to separate them, I asked him to stop. It just doesn't work; at that time I couldn't do anything. I can't hit my dad. That was in the middle of the night, my mother worked in a pizzeria and the pizzeria closed at that time. [...] and he was bad, he would hit her, and we would wake up and see that ... We shouted for help, but nobody helped (F10).

Every time that he (father) wanted to use drugs and had to get money then he sold things from home... My mother got separated from him, but he still stole things, but then we moved to another city (F11).

The following statements show that drinking was encouraged and beverages were offered by family members, usually when those directly responsible were not present, reiterating the results of the quantitative data with regards of a greater likelihood of using from those who do not live with both parents, and thus inferring that parental surveillance is essential in adolescence.

At home [place of use], my mother was not there, only my father. [The drink was offered by his 14-year-old cousin] (F13).

Ahhh my stepfather, my father doesn't live with me, my stepfather lets me [drink]. At parties he drinks with me. Like on my 15th birthday we drank together. (F9).

The third subcategory regards the use of PAS and its relationship with friends. The adolescents report that the use of PAS depends to a large extent on the cycle of friendships. This corroborates and complements the data according to which adolescents whose friends drink are the most likely to drink.

You have a friend, a very good friend who drinks and has friends... that also drink... since they are people that you admire and are your friends, you will end up wanting to follow them, then you end up drinking and entering the world of drugs or alcohol (M6).

But despite recognizing that there is an influence from friends, adolescents describe that it depends a lot on whether the individual wants to use it or not, the influence being only one of the components of the use of PAS.

Mine do not [influence of friends]. We go because we want to, then we say that we were influenced, just to be saint and a victim, but we go because we want to! (F10)

If I had more friends who used it and I had, let's say, a weaker mind, I would use it (M18).

Thus, adolescents partly assume responsibility for the use of alcohol, as if it were related to a vulnerability in a person's character.

Two issues that differentiated adolescents who use PAS from those who do not use them were their friendships and the places they go to. The following statements are from adolescents who did not use alcohol.

I don't really like going out. I prefer to stay home. Stay there. Even they [parents] keep saying "go out, you stay home all the time." I don't like to (M14).

My friends are very similar to me. They don't go to these parties, they are more like staying at home, they like to play games, just like I do. Like, I spend most of my time playing on my Playstation and my friends too... none of them drink or smoke [...] (M6).

The behavior of adolescents who did not drink is plainer, showing that social relationships are important and there is an approximation of individuals with similar behaviors. As for adolescents who used alcoholic beverages, when asked how they had fun, they had different responses.

I don't go out that much. Friday sometimes, because I work on Saturdays and Sundays. Then I go out on Fridays, there is a weekend that I go out, but it is very difficult forme to go out like this ... Friday, Saturday and Sunday, I usually go out only on Friday. We go to a lot of socials and parties and stuff. A "social" is a party at 
a friend's house, you only take what you'll drink and eat (M15).

Now that I have come to this school my friends ask me out, sometimes they ask me to drink then I get a little like, you know ... then I drink from time to time (F7).

In the statements above, there is a part about going out on weekends. In the city studied, there is a relationship between fun and the use of drinks, with few leisure options that do not involve the use of alcohol. The pastimes of most people, on weekends, are limited to bars with no green areas, parks, exhibitions, or shows in the city. When there are drinks, they are heavily consumed. Thus, adolescents report that they go out on weekends, reproducing the local culture.

\section{口ISCUSSION}

Normative institutions such as the school are important when analyzing the relationships of adolescents with the use or not of PAS, since it is in this social space that they expand their social range, previously restricted to the family. In the multiple analysis of the data, there was no greater probability of alcohol use related to the type of school, which corroborates the adolescents' speeches.

This large use of PAS must be analyzed in a broader context, in which the school is influenced by the general dimension, related to government policies and ideology of parents and the community in which it is inserted ${ }^{(12)}$. Due to these macrosocial forces, it ends up reproducing current paradigms, such as marginalization of the drug user and moralistic and biologicist views of the phenomenon, thus failing to redefine the theme ${ }^{(5)}$.

Teachers try to work on the subject, but due to personal and professional training, they end up further deepening the current paradigms. This is related to factors such as the devaluation of teachers and principals who do not often have the theme of PAS use in their syllabuses, in addition to the lack of permanent education related to knowing the reality of the territory and possible actions. This lack of investment or urgency in changing the current reality has economic interests, aiming to reproduce current social and cultural structures ${ }^{(13)}$

The family also emerges as an important factor for the discussion, because just as the school is an institution, the family is the individual's first institution.lt is through a person's family that they are constructed, through observing transgenerational behaviors that will build their social learning. They tend to reproduce behaviors and pass them on to future generations, making prejudices and stereotypes become ingrained in society ${ }^{(14)}$.

When qualitative and quantitative data are integrated, it is possible to relate the socioeconomic factors with the use or not of drinks, because, as the analysis indicate, not living with parents is a determinant risk for the use of alcohol. In contrast, maternal educational levels were not associated with this use, which can be interpreted based on the high rate (33.3\%) of mothers with higher education in the survey, although the PeNSE (2015) $)^{(3)}$ research showed a percentage of only $13,3 \%$. A high maternal educational level can be perceived as a protective factor for this adolescent, being associated with less social vulnerability ${ }^{(15)}$.

Analyzing the issues related to the family and the spaces this adolescent frequents, it is a fundamental factor, in addition to being the basis for the discussion of social determination, the social inequality, which can be perceived when adolescents from poorer neighborhoods report greater family losses due to PAS use, when compared to adolescents in better economic situations. Socioeconomic factors lead to a condition of vulnerability that will cause oppression and social exclusion ${ }^{(8,15)}$.

Within these social spaces, adolescents associate with other young people who share their worldviews or who have behaviors that the adolescent wants to share, among which behaviors is alcohol consumption, which is socially desirable and stimulated. Thus, the teenager ends up drinking or looking for people who do so, to feel like they belong to a social group that can be considered influential(16-17).

Both axis from this research show friendship as a decisive factor for the consumption of PAS by adolescents. However, they show an opposite view about the same factor throughs statements according to which the use of SPAs is related to individual choice, and that alcohol abuse is due to a character vulnerability. The adolescent relates use to choice, since the desire to drink is subjective, so they believe that it was an individual choice, but in fact there are several general and particular determinants that lead to this choice, such as media, television ads, and social networks ${ }^{(16,18)}$.

Regarding the relation between space and the consumption of SPAs, it has to be said that although the city has neighborhoods with different infrastructures and income, and its inhabitants visit the downtown region on weekends, the form of occupation of the spaces differs according to 
social class, with young people with less financial conditions drinking in the streets and squares, and those with better conditions, in bars and friends' houses.

The study limitations were related to the fact that this is a study based on self-reports on risk behaviors, which can lead to omission or underestimation of the reports by the respondents. A study on the reliability of the PeNSE instrument questions ${ }^{(3)}$ demonstrated that the PAS questions were the ones that had the greatest inconsistency ${ }^{(19)}$. As a way of limiting possible omissions, the researchers explained about ensuring anonymity in the participating schools.

Other limitations are related to the study having occurred only in schools, apprehending only the reality of the adolescents who attend these places, failing to capture the reality of those who are outside the classroom. Finally, the study occurred only in one city, but its results may reflect the national reality, mainly due to the results of the qualitative design being very similar to those of PeNSE (2015) $)^{(3)}$.

\section{finAL CONSIDERATIONS}

This study aimed to understand the relationship between space and the use of SPAs by adolescents, capturing how the relationships occur in their social space and how they are related to their opinion and behaviors regarding the use of PAS.

Based on observation, the adolescents end up reproducing social behaviors and statements considered correct by the community in which they are inserted. Thus, when thinking about interventions in the context of the use of SPAs by adolescents, the social space they come from should be considered. Their actions should not be considered only from an individual level, but should also be thought to involve family and community. These actions must take place in health units, with nurses as a pillar in this movement, since they present expertise in carrying out health education due to their training, especially in schools, which is the place where young people stay the longest.

As a limitation of this study, it was based on self-reports on topics considered taboos, which can lead to omission or underestimation of patterns of use. Another limitation is regarding its focus, which was only on adolescents regularly enrolled and frequent at classes, failing to apprehend the reality of PAS use by adolescents who are not at school.

\section{REFERENCES}

1. Liu Y, Lintonen T, Tynjala J, Villberg J, Valimaa R, Ojala K et al. Socioeconomic differences in the use of alcohol and drunkenness in adolescents: trends in the health behaviour in school-aged children study in Finland 1990-2014. Scand J Public Health. 2018;46(1):102-11. doi: https://doi. org/10.1177/1403494816684118

2. Jorge KO, Ferreira RC, Ferreira EP, Vale MP, Kawachi I, Zorzar PM. Binge drinking and associated factors among adolescents in a city in southeastern Brazil: a longitudinal study. Cad SaúdePública. 2017 Mar;33(2):e00183115. doi: https://doi.org/10.1590/0102-311x00183115

3. Instituto Brasileiro de Geografia e Estatística. Pesquisa Nacional de Saúde Escolar 2015. Rio de Janeiro: Instituto Brasileiro de Geografia e Estatística; 2016.

4. Tapert SF, Schweinsburg AD, Barlett VC, Brown SA, Frank LR, Brown GG, et al. Blood oxygen level dependent response and spatial working memory in adolescents with alcohol use disorders. Alcoholism: clin experim res. 2004;28(10):1577-86. doi: https://doi.org/10.1097/01.alc.0000141812.812 34.26

5. Almeida MR, Gomes RM. Medicalização social e educação: contribuições da determinação social do processo saúde-doença. Nuances. 2014; 25(1):15575. doi: https://doi.org/10.14572/nuances.v25i1.2728

6. Santos M. Espaço e sociedade. Petrópolis: Vozes; 1979.

7. Oliveira LFR, Gomes MJM, Soares E, Cavalcante MAF, Nascimento EGC. Consumption of alcohol by adolescents: from the act of liberty to risk behavior. Adolesc Saúde. 2017 [cited 2019 Aug 2];14(2):58-65. Available from: http:// adolescenciaesaude.com/detalhe_artigo.asp?id=650\&idioma=English

8. Breilh J. Episteme e práxis social: como se transformam, avançam ou retrocedem os conceitos cientificos. In: Breilh J. Epidemiologia crítica: ciência emancipadora e interculturalidade. Rio de Janeiro: Editora FIOCRUZ; 2006. p. 99-111.

9. Creswell JW, Plano Clark VL. Pesquisa de métodos mistos. 2a ed. Porto Alegre: Penso; 2013.

10. Saunders B, Sim J, Kingstone T, Baker S, Waterfield J, Bartlam B, et al. Saturation in qualitative research: exploring its conceptualization and operationalization. Qual Quant. 2018;52(4):1893-907. doi: https://doi. org/10.1007/s11135-017-0574-8

11. Alencar TO, Nascimento MA, Alencar BR. Hermenêutica dialética: uma experiência enquanto método de análise na pesquisa sobre 0 acesso do usuário a assistência farmacêutica. Rev Bras Promoc Saúde. 2012 [cited 2019 Aug 10];25(2):243-50. Available from: https://periodicos.unifor.br/RBPS/ article/view/2236

12. Borde $E$, Alvarez MH, Porto MFS. Uma análise crítica da abordagem dos determinantes sociais da saúde a partir da medicina e saúde coletiva latino-americana. Saúde Debate. 2015;39(106):841-54. doi: https://doi. org/10.1590/0103-1104201510600030023

13. Olenski MCB, Chaves EMS. A reinserção social do dependente de substâncias psicoativas: um debate contemporâneo. Rev Inst Pesq Estudos. 2014 [cited 2019 Aug 5];18(34):1-87. Available from: http://ojs.ite.edu.br/index.php/ css/article/view/146/0 
14. Galhardi CC, Matsukura TS. 0 cotidiano de adolescents em um centro de atenção psicossocial de álcool e outras drogas: realidades e desafios. Cad Saúde Pública. 2018;34(3):e00150816. doi: https://doi.org/10.1590/0102-311x00150816

15. Almeida RMM, Trentini LB, Klein LA, Macuglia GR, Hammer C, Tresmmer M. Uso de álcool, drogas, níveis de impulsividade e agressividade em adolescentes do Rio Grande do Sul. Psico. 2014;45(1):65-72. doi: http://doi. org/10.15448/1980-8623.2014.1.12727

16. Deodato S, Nunes E, Capelas M, Seabra P, Santos AS, Garcia LM. Risk behaviors to psychoactive substances use in children and young people in Lisbon. Enferm Glob. 2017;16(47):98-127. doi: https://doi.org/10.6018/eglobal.16.3.253011

17. Pettigrew S, Biagioni N, Jongenelis Ml. Anticipating and addessing eventspecific alcohol consumption among adolescents. BMC Public Health. 2016;16:661. doi: https://doi.org/10.1186/s12889-016-3355-8
18. Torronen J, Roumeliotis F, Samuelsson E, Kraus L, Room R. Why are people drinking less than earlier? identifying and specifying social mechanisms with a pragmatist approach. Int Drug Policy. 2019;64:13-20. doi: https://doi. org/10.1016/j.drugpo.2018.12.001

19. Ramos D0, Daly M, Seidl-de-Moura ML, Jomar RT, Nadanovsky P. Inconsistent reports of risk behavior among Brazilian middle school students: National School Based Survey of Adolescent Health (PeNSE 2009/2012). Cad Saúde Pública. 2017;33(4):e00145815. doi: https://doi.org/10.1590/0102-311×00145815

\section{Acknowledgments:}

This study was funded through a research grant from the Ministry of Health of Brazil (Project n o: 86/25000.192056/2014-16).

\section{- Corresponding author:}

Camila Souza de Almeida

E-mail: csalmeida_1@hotmail.com

\section{Associate editor:}

\section{Editor-in-chief:}

Maria da Graça Oliveira Crossetti 